\title{
ANTI-INFLAMMATORY EFFECTS OF AN AQUEOUS EXTRACT OF JUSTICIA FLAVA (FORSK) VAHL (ACANTHACEAE) IN RATS
}

\author{
KOUAME DJÈ KOUAMÉ WENCESLAS*, N’DIA KOUADIO FRÉDÉRIC, KOUAKOU KOUAKOU LÉANDRE, \\ YAPO ANGOUÉ PAUL
}

Department of Natural Sciences, Laboratory of Physiology, Pharmacology and Pharmacopoeia, Nangui Abrogoua University, Abidjan - Côte d'Ivoire; BP 801 Abidjan 02, Côte d'Ivoire. Email: kouamedjekw@outlook.fr

Received: 08 April 2021, Revised and Accepted: 20 July 2021

ABSTRACT

Objective: Justicia flava is a plant commonly used in traditional medicine for the treatment of frictions, convulsions, body aches, pains, and fever. The aim of this study was to determine the anti-inflammatory properties of an aqueous extract of $J$. flava (AEJf) in rats.

Methods: Thus, 36 rats were divided into six groups of six rats each for each test. Acute anti-inflammatory activity was evaluated by induction of plantar edema following injections of egg albumin, carrageenan, or histamine. AEJf and aspirin (100 mg/kg bw) were orally administered to rats with doses ranged from 62.5 to $500 \mathrm{mg} / \mathrm{kg}$ bw before (preventive study) and after (curative study) the induction of edema. The rat's paw edema was measured using a digital caliper thereafter. For a sub-chronic anti-inflammatory activity, sterilized cotton pellets (20 $\pm 0.5 \mathrm{mg}$ ) were implanted in the anterior dorsal region for granuloma formation. Animals received the different doses of AEJf (62.5-500 mg/kg bw) for 7 days and on the $8^{\text {th }}$ day, cotton pellets were removed and weighed, dried, and weighed again.

Results: The results of the oral administration of AEJf at doses of $62.5,125,250$, and $500 \mathrm{mg} / \mathrm{kg}$ bw to rats showed similar acute anti-inflammatory properties such as aspirin (100 mg/kg bw) on carrageenan (1\%), fresh egg albumin, and histamine injection-induced rats' paw edema. AEJf caused $77.63 \%$ (preventive study) and $28.1 \%$ (curative study) inhibitions of carrageenan (1\%) solution-induced paw edema and $61 \%$ (preventive study) and $29.62 \%$ (curative study) inhibitions of fresh egg albumin-induced paw edema. AEJf also inhibited histamine-induced edema (1 mg/mL) by $83.67 \%$ compared to the control group. AEJf significantly reduced the weight of granuloma tissue elicited by the insertion of sterile cotton pellets from 34.53 to $46.98 \%$ for wet cottons and from 45.73 to $59.45 \%$ for dry cottons.

Conclusion: AEJf possessed anti-inflammatory activity on acute and sub-chronic inflammations in rats.

Keywords: Justicia flava, Anti-inflammatory, Edema, Granuloma, Rats.

(C) 2021 The Authors. Published by Innovare Academic Sciences Pvt Ltd. This is an open access article under the CC BY license (http://creativecommons.org/ licenses/by/4.0/) DOI: http://dx.doi.org/10.22159/ajpcr.2021v14i8.41977. Journal homepage: https://innovareacademics.in/journals/index.php/ajpcr

\section{INTRODUCTION}

Inflammation is a defense mechanism of the body and also an essential immune response that allows body cells to survive during infection or injury and to maintain tissues homeostasis [1]. It is a localized protective reaction of tissues, cells of the body in allergic or chemical irritations and in infections caused by wounds [2]. In addition, inflammation is characterized by pain, heat, redness, and edema [3].Conventional medicine uses steroidal and nonsteroidal anti-inflammatory drugs for the treatment of inflammation. Unfortunately, their prolonged use could lead to gastrointestinal tract disorders, kidney, and skin toxicities [4].

Traditional or alternative medicine is widely used to treat inflammatory diseases and pain as well. Therefore, to limit or avoid the harmful effects of these drugs, traditional medicine can be an alternative. In this perspective, this study was conducted on Justicia flava (Forsk) Vahl (Acanthaceae), a plant commonly used as a hemostatic agent, against seizures, and febrile body aches [5]. In addition, J. flava is used against feverish pain and children diarrhea [6]. The inhibitory activity of J. flava on the angiotensin I converting enzyme, the biological activity and the determination of the constituents of J. flava and several other species of Justicia have previously been assessed $[7,8]$. The pharmacological and chemical studies of a selection of medicinal species of Justicia from Asia and America have been carried out [9]. The results of these different studies showed that J. flava possesses phytocompounds such as flavonoids, sterols, salicylic acid, lignin, and docosanoic acid. The antimicrobial effect and wound healing power of J. flava were revealed by Agyare et al. [10]. However, no study on the anti-inflammatory activity of this plant has been mentioned yet. These works were, therefore, undertaken to evaluate the anti-inflammatory potential of an aqueous extract of J. flava (AEJf).

\section{METHODS}

\section{Material}

Plant

Herbaceous plants of J. flava were harvested in Petit Yapo, a village in the department of Agboville (Côte d'Ivoire). They were identified by botanists in the laboratory of botany of Nangui Abrogoua University (Abidjan, Côte d'Ivoire) and authenticated at the National Floristic Center under the voucher number 17511 of July 29, 1986.

Animals

Albino rats (Rattus norvegicus), weighing between $180 \mathrm{~g}$ and $200 \mathrm{~g}$, were used. They were kept in cages in the laboratory of physiology and pharmacology animal house of the University of Nangui Abrogoua. These animals were 8-10 weeks old and had free access to water and standard food for rodents (Ivograin ${ }^{\circledR}$ pellets). They were submitted to a $12 \mathrm{~h}$ dark/light photoperiod cycle. Rats were treated according to the good laboratory practice [11]. The different experimental protocols were followed in accordance with the experimental animal protection protocols of the European Council on Legislation 2012/707 [12].

\section{Chemicals}

Carrageenan (Sigma-Aldrich, France), albumin contained in fresh egg white, histamine (Sigma-Aldrich, France), aspirin ${ }^{\circledR}$ (Cipharm, Côte 
d'Ivoire), normal saline solution ( $\mathrm{NaCl}, 9 \%)$, and diethyl ether (VWR International, Leuven-Belgique) were used in this study.

\section{Methods}

Preparation of the AEJf

The whole plant of J. flava (leaves, flowers, inflorescences, and stem) except the root was used in this study. Harvested plants of J. flava were washed with distilled water and dried at room temperature $\left(22-24{ }^{\circ} \mathrm{C}\right)$ and thereafter pulverized using an electric grinder (RETSH, type SM 100 , Germany). $100 \mathrm{~g}$ of powder were decocted for $15 \mathrm{~min}$ in 1-1 distilled water. The aqueous solution obtained was respectively filtered on hydrophilic cotton and Whatman filter paper $\mathrm{N}^{\circ} 3$. The filtrate was evaporated and dried using an oven (Selecta, Belgique) at $45^{\circ} \mathrm{C}$ for $48 \mathrm{~h}$. The dark-green powder (14.37 g) corresponded to the AEJf.

\section{Acute anti-inflammatory activity of the extract}

The evaluation of the reduction of rats' plantar edema caused by the injection of phlogogenic agents (carrageenan, egg albumin, and histamine) was performed according to the method described by Winter et al. [13]. Thus, six groups of six rats were formed for each model of experiment. The rats were fasted $16 \mathrm{~h}$ before the beginning of the experiment. The initial thickness of the right hind paw of each rat was measured using a digital micrometer (Hardened Stainless, China) commonly known as Vernier caliper. The rats in group 1, administered with $\mathrm{NaCl}(9 \%)$ solution at $10 \mathrm{~mL} / \mathrm{kg}$ bw, constituted the negative control group. As for the rats in groups 2, 3, 4, and 5, they received, by gavage, the total AEJf at doses of $62.5,125,250$, and $500 \mathrm{mg} / \mathrm{kg} \mathrm{BW}$, respectively, after preliminary trials. The rats in Group 6, the positive control group, were gavaged with acetylsalicylic acid $\left(\right.$ Aspirin $\left.^{\circledR}\right)$ at a dose of $100 \mathrm{mg} / \mathrm{kg} \mathrm{bw}$.

Inflammation preventive activity of the extract

One hour after rats were administered with the plant extract, different rats' groups received plantar injection in the right hind paw with either $0.1 \mathrm{~mL}$ of carrageenan $(1 \%)$ solution, $0.1 \mathrm{~mL}$ of fresh egg albumin or $0.1 \mathrm{~mL}$ of histamine $(1 \mathrm{mg} / \mathrm{mL})$. Finally, the edema of that paw was measured again $1 \mathrm{~h}, 2 \mathrm{~h}, 3 \mathrm{~h}, 4 \mathrm{~h}$, and $5 \mathrm{~h}, 6 \mathrm{~h}$ (for carrageenan and histamine) later using the digital micrometer. These determined edema outcome values were used to calculate the percentage of inhibition of the edema (\% INH) according to the formula used by Meshram et al. and Gutiérrez-Rebolledo et al. [14,15].

$$
\% \mathrm{INH}=\frac{(\mathrm{Dt}-\mathrm{Do}) \text { negative control }-(\mathrm{Dt}-\mathrm{Do}) \text { treated group }}{(\mathrm{Dt}-\mathrm{Do}) \text { negative control }} \times 100
$$

Do: Diameter of the right hind leg at initial time Dt: Diameter of the right hind leg at time $t$.

Inflammation curative activity of the extract Edema was induced in each rat $1 \mathrm{~h}$ (egg albumin) or $2 \mathrm{~h}$ (carrageenan) by injecting either $0.1 \mathrm{~mL}$ of carrageenan (1\%) solution or $0.1 \mathrm{~mL}$ of fresh egg albumin under the paw of the right hind leg before the gavage with AEJf or normal saline. The thickness of the edema was measured, as previously. After the different treatments, the thickness of the paw was measured again after 1, 2, 3, 4, and $5 \mathrm{~h}$. The determined values were used to calculate the percentage of reduction in rat paw thickness (\% reduction) to estimate the effectiveness of the treatments on rats induced paw edema according to the formula used in the work of Muhammad et al. [16].

$$
\% \text { Réduction }=\frac{\mathrm{A}-\mathrm{B}}{\mathrm{A}} \times 100
$$

A: thickness of the edema of the negative control rats' group.

B: thickness of the edema measured 1, 2, 3, 4, or $5 \mathrm{~h}$ after treatments

\section{Subchronic anti-inflammatory activity}

Cotton pellet-induced granuloma

The method described by Kumar et al. [17] was used for this test with slight modifications. Thus, 36 rats were randomly divided into six groups of six rats each. Group I or negative control group received by gavage $\mathrm{NaCl}(9 \%)$ solution at $10 \mathrm{~mL} / \mathrm{kg}$ bw. Groups II, III, IV, and $\mathrm{V}$ received by gavage the total $\mathrm{AEJf}$ at the respective doses of 62.5; 125; 250; and $500 \mathrm{mg} / \mathrm{kg}$ bw. Group VI or positive control group was administered by gavage with aspirin ${ }^{\circledR}(100 \mathrm{mg} / \mathrm{kg}$ bw). The various treatments $\left(\mathrm{NaCl}, \mathrm{AEJf}\right.$ and aspirin $\left.{ }^{\circledR}\right)$ were applied daily for 7 successive days to the rats. On the $1^{\text {st }}$ day, $1 \mathrm{~h}$ after treatment, two sterilized autoclaved cotton pellets $(20 \pm 0.5 \mathrm{mg})$ were implanted in the dorsal anterior region of the pre-shaved and anesthetized rats with diethyl ether. On the $8^{\text {th }}$ day, the animals were anesthetized with ether. The cotton pellets were dissected, freed from tissue attachments, weighed, and then dried in an oven (Selecta, Belgique) for $24 \mathrm{~h}$ at $60^{\circ} \mathrm{C}$ until a constant weight was obtained. The final weight of the dried cotton pellets was further determined.

The weight of the granuloma contents was calculated as described below:

Weight of wet granuloma content $=$ weight of the wet cotton pellet weight of the initial cotton pellet.

Weight of dry granuloma content $=$ weight of the dry cotton pellet weight of the initial cotton pellet.

The inhibition percentage of granuloma tissue formation was calculated according to the formula described by Kumar et al. [17].

$$
\% \text { Inhibition }=\frac{(\mathrm{Tc}-\mathrm{Tt})}{\mathrm{Tc}} \times 100
$$

Tc: weight of granuloma tissue of the control group $\mathrm{Tt}$ : weight of granuloma tissue of the treated group.

Measurement of the rats body weight

To evaluate the evolution of the body weight of the rats throughout the study period, a scale (Digital scal-SF-400, China) was used for weighing the rats on days 0 and 8 of the experimentation.

Blood sampling and hematological parameters determination Blood samples were taken at the beginning (day 0) and at the end (day 8) of the experiment in rats previously anesthetized with diethyl ether by the method of puncture on the retro-orbital sinus of the eye. Blood samples were collected and kept into EDTA tubes. They were placed in a cooler containing ice and sent to the laboratory for hematological parameters (white blood cell, red blood cell, and platelet count) analyses thanks to the Culter (RAYTO-RT 7600S, China), an automatic hematology analyzer.

\section{Statistical analysis}

The results were presented as mean followed by the standard error on the mean $(\mathrm{M} \pm \mathrm{SEM})$. Statistical analysis was performed using the GraphPad Prism 5.01 software (San Diego, California, USA). The test $t$ of Student was used. It was completed with the one-way analysis of variance (ANOVA1) followed by the Dunnett comparison test to reveal the differences between the treated groups and the control one. The differences were significant for $\mathrm{p}<0.05$.

\section{RESULTS}

\section{Acute inflammation study}

Preventive effect of the AEJf on carrageenan-induced edema in rats

Before the induction of inflammation with carrageenan, the mean thickness of the rats' legs was between $2.49 \pm 0.06$ and $2.63 \pm 0.06 \mathrm{~mm}$. After the injection of carrageenan, the average thickness of the paw of the control rats underwent a maximum increase ranging from $2.49 \pm 0.06 \mathrm{~mm}$ (initial state) to $4.84 \pm 0.18 \mathrm{~mm}$ ( $3 \mathrm{~h}$ later) and decreased non significantly to $4.01 \pm 0.16 \mathrm{~mm}(6 \mathrm{~h}$ later $)$. The pretreatment of the rats with the AEJf caused a significant inhibition in edema compared to controls. 
The inhibition of edema in rats pretreated at $62.5 \mathrm{mg} / \mathrm{kg}$ bw with the extract varied from $46.94 \%\left(1^{\text {st }} \mathrm{h}\right)$ to $61.18 \%\left(6^{\text {th }} \mathrm{h}\right)$ compared to control. The inhibition in edema was higher in rats pretreated with the extract at doses of 125 and $250 \mathrm{mg} / \mathrm{kg}$ bw than those pretreated with the dose of $62.5 \mathrm{mg} / \mathrm{kg}$ bw. These inhibitions were ranged from 39.74 to $66.45 \%$ and from 41.02 to $70.39 \%$, respectively. At $500 \mathrm{mg} / \mathrm{kg}$ bw, the total AEJf exhibited a maximum inhibition in edema ranging from 52.04 to $77.63 \%$ compared to control. As for the rats administered with aspirin $^{\circledR}$, the inhibition percentage in edema was between 43.87 and $82.89 \%$ compared to control rats (Table 1).

Preventive effect of the AEJf on fresh egg albumin-induced edema in rats The administration of the AEJf at doses ranging from 62.5 to $500 \mathrm{mg} / \mathrm{kg}$ bw significantly inhibited paw edema induced by the injection of fresh egg albumin in the rats. The initial average thickness of the paw varied from $2.94 \pm 0.06 \mathrm{~mm}$ to $3.13 \pm 0.04 \mathrm{~mm}$ in the control group.

The injection of egg albumin caused an increase in the average thickness of the rats' paw with values between $4.09 \pm 0.12$ and $6.17 \pm 0.16 \mathrm{~mm}$ during the $5 \mathrm{~h}$ of the experimentation. Paw edema of the rats pretreated with the AEJf at the dose of $62.5 \mathrm{mg} / \mathrm{kg}$ bw was inhibited from $36.87 \%$ to $46.71 \%$ compared to the control group during the $5 \mathrm{~h}$. In rats pretreated with 125 and $250 \mathrm{mg} / \mathrm{kg}$ of the extract, inhibitions were similar to those observed in rats pretreated with $62.5 \mathrm{mg} / \mathrm{kg}$ bw of AEJf. At these doses, the inhibition of edema ranged from 33.12 to $60.36 \%$ and from 34.77 to $49.80 \%$, respectively, compared to the control. At
$500 \mathrm{mg} / \mathrm{kg}$ bw, the extract induced maximum inhibitions of edema of $61.00 \%\left(2^{\text {nd }} \mathrm{h}\right)$ and $58.55 \%\left(5^{\text {th }} \mathrm{h}\right)$. Aspirin ${ }^{\circledR}$, the standard drug, reduced edema in rats from $39.81 \%$ to $60.36 \%$ (Table 2). Photographs of the right hind paw of rats treated with the AEJf and aspirin ${ }^{\circledast}$ showed a reduction in swelling (Fig. 1).

\section{Anti-inflammatory effect of the AEJf on histamine-induced edema}

The pretreatment of rats with the AEJf at doses ranging from 62.5 to $500 \mathrm{mg} / \mathrm{kg}$ bw significantly reduced histamine-induced paw edema in rats from the $2^{\text {nd }}$ to the $6^{\text {th }} \mathrm{h}$ of experiment. The initial mean thickness of the rats paw was homogeneous and varied between $2.23 \pm 0.05$ and $2.38 \pm 0.03 \mathrm{~mm}$. The histamine injection elicited a maximum increase in the average thickness of the control rats paw of $4.31 \pm 0.15 \mathrm{~mm}$ at the $3^{\text {rd }} \mathrm{h}$ of the experiment. Edema in the paw of rats treated with the AEJf and aspirin underwent non-significant inhibitions ranging from $20.08 \%$ to $36.40 \%$ compared to the control group at the $1^{\text {st }} \mathrm{h}$. From the $2^{\text {nd }} \mathrm{h}$, edema in the paw of rats treated with the AEJf at doses of $62.5 \mathrm{mg} /$ $\mathrm{kg}$ bw dropped significantly from $49.66 \%$ to $62.57 \%$ at the $4^{\text {th }} \mathrm{h}$ and finally reached $56.12 \%$ at the $6^{\text {th }} \mathrm{h}$ compared to the control group. The inhibitions of edema in rats pretreated with the extract attained $83.67 \%$ at the $6^{\text {th }} \mathrm{h}$ for the dose of $125 \mathrm{mg} / \mathrm{kg}$ bw and 83.04 at the $4^{\text {th }} \mathrm{h}$ for that of $250 \mathrm{mg} / \mathrm{kg}$ bw. At $500 \mathrm{mg} / \mathrm{kg}$ bw, the extract triggered inhibitions with maximum value of $76.53 \%$ at the $6^{\text {th }} \mathrm{h}$ of experiment compared to control. Aspirin ${ }^{\circledR}$ caused a significant reduction in histamine-induced rats paw edema with values ranging from 52.34 to $76.02 \%$ compared to control (Table 3).

Table 1: Preventive effect of the AEJf on carrageenan-induced edema in rats

\begin{tabular}{|c|c|c|c|c|c|c|c|}
\hline \multirow[t]{2}{*}{$\begin{array}{l}\text { Treatment and doses } \\
\text { (mg/kg bw) }\end{array}$} & \multirow[t]{2}{*}{$\begin{array}{l}\text { Paw thickness }(\mathrm{mm}) \text { before } \\
\text { injection of carrageenan }\end{array}$} & \multicolumn{6}{|c|}{$\begin{array}{l}\text { Paw thickness }(\mathrm{mm}) \text { after carrageenan injection } \\
\text { (edema inhibition percentage) }\end{array}$} \\
\hline & & $1 \mathrm{~h}$ & $2 \mathrm{~h}$ & $3 \mathrm{~h}$ & $4 \mathrm{~h}$ & $5 \mathrm{~h}$ & $6 \mathrm{~h}$ \\
\hline $\begin{array}{l}\text { Normal saline (control) } \\
(\mathrm{mL} / \mathrm{kg} \mathrm{bw})\end{array}$ & $2.49 \pm 0.06$ & $3.47 \pm 0.11$ & $4.05 \pm 011$ & $4.84 \pm 0.18$ & $4.55 \pm 0.20$ & $4.34 \pm 0.22$ & $4.01 \pm 0.16$ \\
\hline AEJf 62.5 & $2.53 \pm 0.04$ & $\begin{array}{l}3.05 \pm 0.06^{*} \\
(46.94)\end{array}$ & $\begin{array}{l}3.31 \pm 0.07^{* *} \\
(50.00)\end{array}$ & $\begin{array}{l}3.52 \pm 0.14^{* * *} \\
(57.87)\end{array}$ & $\begin{array}{l}3.35 \pm 0.11^{* * *} \\
(60.19)\end{array}$ & $\begin{array}{l}3.29 \pm 0.18^{* * *} \\
(58.91)\end{array}$ & $\begin{array}{l}3.12 \pm 0.21 * * * \\
(61.18)\end{array}$ \\
\hline AEJf 125 & $2.57 \pm 0.04$ & $\begin{array}{l}3.06 \pm 0.09 * \\
(50.00)\end{array}$ & $\begin{array}{l}3.51 \pm 0.18^{*} \\
(39.74)\end{array}$ & $\begin{array}{l}3.93 \pm 0.169^{* *} \\
(42.12)\end{array}$ & $\begin{array}{l}3.44 \pm 0.15^{* * *} \\
(57.76)\end{array}$ & $\begin{array}{l}3.24 \pm 0.15^{* * *} \\
(63.78)\end{array}$ & $\begin{array}{l}3.08 \pm 0.09^{* * *} \\
(66.45)\end{array}$ \\
\hline AEJf 250 & $2.51 \pm 0.04$ & $\begin{array}{l}3.01 \pm 0.13^{*} \\
(48.98)\end{array}$ & $\begin{array}{l}3.43 \pm 0.16^{*} \\
(41.02)\end{array}$ & $\begin{array}{l}3.54 \pm 0.17^{* * *} \\
(56.17)\end{array}$ & $\begin{array}{l}3.32 \pm 0.18^{* * *} \\
(60.67)\end{array}$ & $\begin{array}{l}3.09 \pm 0.17^{* * *} \\
(68.65)\end{array}$ & $\begin{array}{l}2.96 \pm 0.04^{* * *} \\
(70.39)\end{array}$ \\
\hline AEJf 500 & $2.60 \pm 0.09$ & $\begin{array}{l}3.07 \pm 0.15^{*} \\
(52.04)\end{array}$ & $\begin{array}{l}3.24 \pm 0.13^{* *} \\
(58.97)\end{array}$ & $\begin{array}{l}3.42 \pm 0.10^{* * *} \\
(65.10)\end{array}$ & $\begin{array}{l}3.28 \pm 0.14^{* * *} \\
(66.99)\end{array}$ & $\begin{array}{l}3.17 \pm 0.12^{* * *} \\
(69.19)\end{array}$ & $\begin{array}{l}2.94 \pm 0.12^{* * *} \\
(77.63)\end{array}$ \\
\hline Aspirin ${ }^{\circledR} 100$ & $2.63 \pm 0.06$ & $\begin{array}{l}3.18 \pm 0.05 \\
(43.87)\end{array}$ & $\begin{array}{l}3.25 \pm 0.06^{* *} \\
(60.25)\end{array}$ & $\begin{array}{l}3.41 \pm 0.12^{* * *} \\
(66.80)\end{array}$ & $\begin{array}{l}3.18 \pm 0.13^{* * *} \\
(73.30)\end{array}$ & $\begin{array}{l}3.00 \pm 0.07^{* * *} \\
(80.00)\end{array}$ & $\begin{array}{l}2.89 \pm 0.06^{* * *} \\
(82.89)\end{array}$ \\
\hline
\end{tabular}

${ }^{*} \mathrm{p}<0.05 ;{ }^{* *} \mathrm{p}<0.01 ;{ }^{* * *} \mathrm{p}<0.001 ; \mathrm{n}=6$ : Differences were significant when values of tested groups were compared to that of control group, at the corresponding time (same column). AEJf: Aqueous extract of Justicia flava

Table 2: Preventive effect of the AEJf on fresh egg albumin-induced edema in rats

\begin{tabular}{|c|c|c|c|c|c|c|}
\hline \multirow[t]{2}{*}{$\begin{array}{l}\text { Treatment and doses } \\
(\mathrm{mg} / \mathrm{kg} \mathrm{bw})\end{array}$} & \multirow[t]{2}{*}{$\begin{array}{l}\text { Paw thickness }(\mathrm{mm}) \text { before } \\
\text { fresh egg albumin injection }\end{array}$} & \multicolumn{5}{|c|}{$\begin{array}{l}\text { Paw thickness }(\mathrm{mm}) \text { after fresh egg albumin injection } \\
\text { (edema inhibition percentage) }\end{array}$} \\
\hline & & $1 \mathrm{~h}$ & $2 \mathrm{~h}$ & $3 \mathbf{h}$ & $4 \mathrm{~h}$ & $5 \mathrm{~h}$ \\
\hline $\begin{array}{l}\text { Normal saline } \\
\text { (control) (mL/kg bw) }\end{array}$ & $2.98 \pm 0.03$ & $6.17 \pm 0.16$ & $5.57 \pm 0.18$ & $4.58 \pm 0.09$ & $4.3 \pm 0.11$ & $4.09 \pm 0.12$ \\
\hline AEJf 62.5 & $3.07 \pm 0.06$ & $\begin{array}{l}5.05 \pm 0.09^{* * *} \\
(37.93)\end{array}$ & $\begin{array}{l}4.45 \pm 0.12^{* * *} \\
(46.71)\end{array}$ & $\begin{array}{l}4.08 \pm 0.11^{* * *} \\
(36.87)\end{array}$ & $\begin{array}{l}3.81 \pm 0.10^{*} \\
(43.93)\end{array}$ & $\begin{array}{l}3.69 \pm 0.11^{*} \\
(44.14)\end{array}$ \\
\hline AEJf 125 & $2.94 \pm 0.06$ & $\begin{array}{l}4.47 \pm 0.12^{* * *} \\
(52.04)\end{array}$ & $\begin{array}{l}4.24 \pm 0.12^{* * *} \\
(49.80)\end{array}$ & $\begin{array}{l}4.01 \pm 0.09 * * * \\
(33.12)\end{array}$ & $\begin{array}{l}3.80 \pm 0.11^{*} \\
(34.84)\end{array}$ & $\begin{array}{l}3.38 \pm 0.10^{* * *} \\
(60.36)\end{array}$ \\
\hline AEJf 250 & $3.08 \pm 0.07$ & $\begin{array}{l}4.85 \pm 0.14^{* * *} \\
(44.51)\end{array}$ & $\begin{array}{l}4.38 \pm 0.09 * * * \\
(49.80)\end{array}$ & $\begin{array}{l}4.13 \pm 0.07^{* * *} \\
(34.37)\end{array}$ & $\begin{array}{l}3.85 \pm 0.12 * \\
(41.66)\end{array}$ & $\begin{array}{l}3.65 \pm 0.08^{* *} \\
(48.64)\end{array}$ \\
\hline AEJf 500 & $3.13 \pm 0.04$ & $\begin{array}{l}4.63 \pm 0.13^{* * *} \\
(52.98)\end{array}$ & $\begin{array}{l}4.14 \pm 0.04^{* * *} \\
(61.00)\end{array}$ & $\begin{array}{l}3.87 \pm 0.05^{* * *} \\
(53.75)\end{array}$ & $\begin{array}{l}3.73 \pm 0.12^{* *} \\
(54.54)\end{array}$ & $\begin{array}{l}3.59 \pm 0.05^{* *} \\
(58.55)\end{array}$ \\
\hline Aspirin $^{\circledR} 100$ & $3.00 \pm 0.06$ & $\begin{array}{l}4.92 \pm 0.27^{* * *} \\
(39.81)\end{array}$ & $\begin{array}{l}4.54 \pm 0.19^{* * *} \\
(40.54)\end{array}$ & $\begin{array}{l}3.94 \pm 0.09 * * * \\
(41.25)\end{array}$ & $\begin{array}{l}3.60 \pm 0.09 * * * \\
(54.54)\end{array}$ & $\begin{array}{l}3.44 \pm 0.08^{* * *} \\
(60.36)\end{array}$ \\
\hline
\end{tabular}

${ }^{*} \mathrm{p}<0.05,{ }^{* *} \mathrm{p}<0.01,{ }^{* * *} \mathrm{p}<0.001, \mathrm{n}=6$ : Differences were significant when values of tested groups were compared to those of control group, at the corresponding time (same column). AEjf: Aqueous extract of Justicia flava 
Curative effect of the aqueous extract of J. flava on carrageenan-induced edema in rats

The average thickness of the rats paw before the injection of carrageenan fluctuated between $2.51 \pm 0.07$ and $2.61 \pm 0.05 \mathrm{~mm}$. Two $\mathrm{h}$ after the injection of carrageenan, the average thickness of the rats paw was significantly increased and varied from $4.59 \pm 0.16$ to $5.61 \pm 0.23 \mathrm{~mm}$. The mean thickness of the paw of the control rats ranged from $5.27 \pm 0.08 \mathrm{~mm} \mathrm{(}\left(1^{\text {st }} \mathrm{h}\right)$ to $4.12 \pm 0.09 \mathrm{~mm}\left(5^{\text {th }} \mathrm{h}\right)$ after treatment with normal saline.

On the other hand, the thickness of the hind leg of rats treated with the AEJf was significantly reduced $(\mathrm{p}<0.05)$ compared to control rats. The reduction in edema recorded was between $4.25 \pm 0.17 \mathrm{~mm}\left(1^{\text {st }} \mathrm{h}\right)$ and

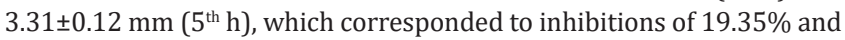
$19.66 \%$, respectively, in rats treated with the AEJf at $62.5 \mathrm{mg} / \mathrm{kg}$ bw. The maximum inhibition $\left(23.11 \%\right.$ ) occurred at the $4^{\text {th }} \mathrm{h}$ after treatment with the extract. The doses of 250 and $500 \mathrm{mg} / \mathrm{kg}$ bw mimicked that of $62.5 \mathrm{mg} / \mathrm{kg}$ bw. The maximum reduction in edema of rats treated with the extract was $28.1 \%$ at the extract dose of $500 \mathrm{mg} / \mathrm{kg}$ bw. Aspirin ${ }^{\circledast}$ caused significant reductions in carrageenan-induced edema with a maximum reduction percentage of $28.15 \%$ by the $4^{\text {th }} \mathrm{h}$ (Table 4 ).
Curative effect of the AEJf on fresh egg albumin-induced edema in rats Before egg albumin injection, the average paw thickness of the different groups of rats was homogeneous with average values ranging from $2.59 \pm 0.32$ to $2.88 \pm 0.23 \mathrm{~mm}$. One hour after the injection of egg albumin, the average thickness of the rats paw was significantly increased $(p<0.001)$ and ranged from $5.99 \pm 0.33$ to $6.68 \pm 0.21 \mathrm{~mm}$. Oral administration of the AEJf at doses ranging from 62.5 to $500 \mathrm{mg} / \mathrm{kg}$ bw caused a significant reduction $(\mathrm{p}<0.05)$ of edema induced by the injection of fresh egg albumin compared to that of the control group. These reductions in edema varied from $8.88 \%$ to $29.62 \%$ with maximum reductions mostly appearing at the $2^{\text {nd }} \mathrm{h}$ of experimentation. Aspirin ${ }^{\circledR}$ significantly diminished egg-albumin edema from $6.49 \pm 0.42$ to $3.28 \pm 0.38 \mathrm{~mm}$ throughout the experiment. The maximum effect of reduction of paw edema recorded after aspirin ${ }^{\circledR}$ administration was $22.3 \%$, at the $1^{\text {st }} \mathrm{h}$ (Table 5 ).

\section{Sub-chronic inflammation study}

Effect of the AEJf on the formation of granuloma induced in rats by cotton pellet

The average weights of wet and dry granuloma contents of the controls $\left(\mathrm{NaCl} 9 \%\right.$ and aspirin $^{\circledR}$ ) groups and those of the AEJf treated

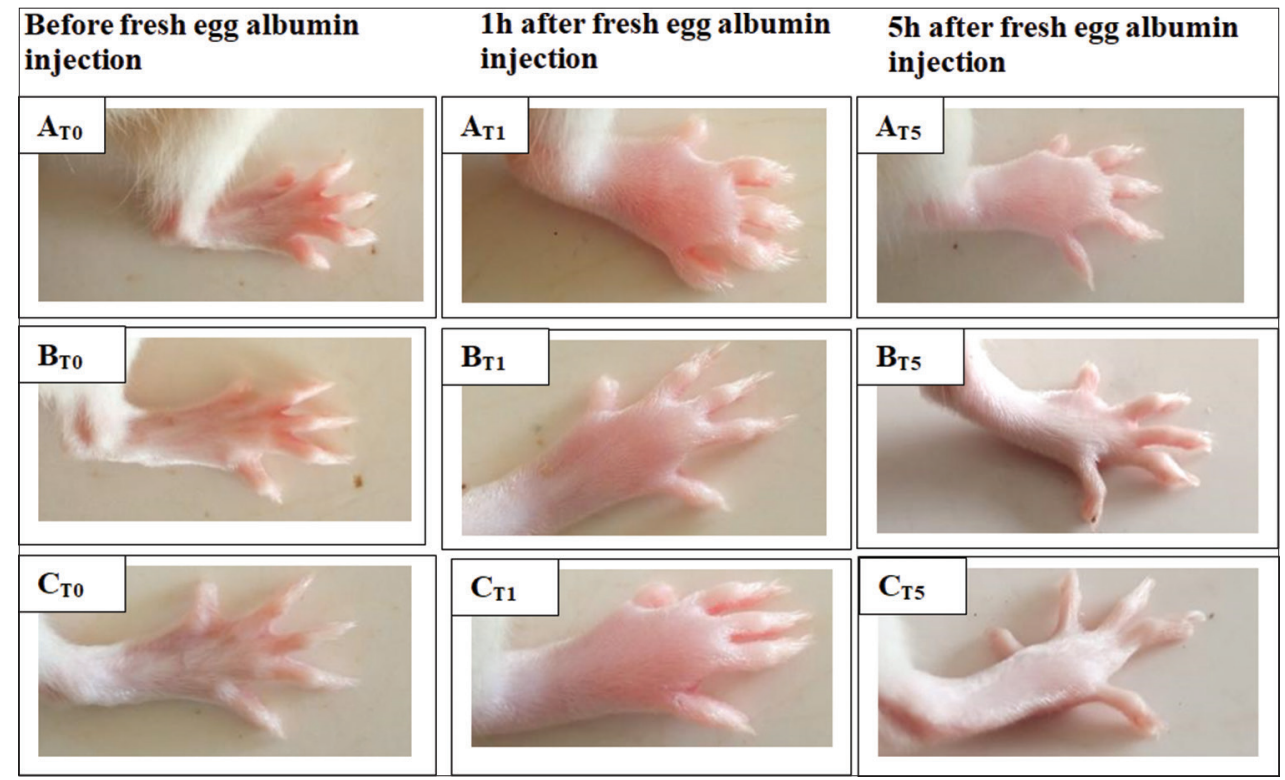

Fig. 1: Photographs of the right hind paws of rats before and after fresh egg albumin injection in rats. (a) Normal saline (control), (b) Aqueous extract of Justicia flava $500 \mathrm{mg} / \mathrm{kg}$ bw, (c) Aspirin ${ }^{\circledR} 100 \mathrm{mg} / \mathrm{kg} \mathrm{bw}$

Table 3: Effect of the AEJf on histamine-induced edema in rats

\begin{tabular}{|c|c|c|c|c|c|c|c|}
\hline \multirow{2}{*}{$\begin{array}{l}\text { Treatment and } \\
\text { doses } \\
(\mathrm{mg} / \mathrm{kg} \mathrm{bw})\end{array}$} & \multirow{2}{*}{$\begin{array}{l}\text { Paw thickness }(\mathrm{mm}) \\
\text { before histamine } \\
\text { injection }\end{array}$} & \multicolumn{6}{|c|}{$\begin{array}{l}\text { Paw thickness }(\mathrm{mm}) \text { after histamine injection } \\
\text { (Edema inhibition percentage) }\end{array}$} \\
\hline & & $1 \mathrm{~h}$ & $2 \mathrm{~h}$ & $3 \mathbf{h}$ & $4 \mathrm{~h}$ & $5 \mathrm{~h}$ & $6 \mathrm{~h}$ \\
\hline $\begin{array}{l}\text { Normal saline } \\
\text { (control) }(\mathrm{mL} / \mathrm{kg} \mathrm{bw})\end{array}$ & $2.23 \pm 0.05$ & $3.17 \pm 0.17$ & $3.72 \pm 0.18$ & $4.31 \pm 0.15$ & $3.94 \pm 0.07$ & $3.37 \pm 0.12$ & $3.21 \pm 0.08$ \\
\hline AEJf 62.5 & $2.38 \pm 0.03$ & $\begin{array}{l}3.07 \pm 0.23 \\
(26.59)\end{array}$ & $\begin{array}{l}3.13 \pm 0.16^{*} \\
(49.66)\end{array}$ & $\begin{array}{l}3.27 \pm 0.22^{* * *} \\
(57.21)\end{array}$ & $\begin{array}{l}3.02 \pm 0.17^{* * *} \\
(62.57)\end{array}$ & $\begin{array}{l}2.85 \pm 0.20^{*} \\
(58.77)\end{array}$ & $\begin{array}{l}2.81 \pm 0.20^{*} \\
(56.12)\end{array}$ \\
\hline AEJf 125 & $2.34 \pm 0.05$ & $\begin{array}{l}2.96 \pm 0.22 \\
(34.04)\end{array}$ & $\begin{array}{l}3.09 \pm 0.20^{*} \\
(49.66)\end{array}$ & $\begin{array}{l}3.29 \pm 0.22^{* * *} \\
(54.32)\end{array}$ & $\begin{array}{l}3.01 \pm 0.17^{* * *} \\
(60.81)\end{array}$ & $\begin{array}{l}2.62 \pm 0.04^{* * *} \\
(75.43)\end{array}$ & $\begin{array}{l}2.50 \pm 0.06^{* * *} \\
(83.67)\end{array}$ \\
\hline AEJf 250 & $2.26 \pm 0.03$ & $\begin{array}{l}3.02 \pm 0.19 \\
(19.14)\end{array}$ & $\begin{array}{l}2.76 \pm 0.04^{* * *} \\
(66.44)\end{array}$ & $\begin{array}{l}2.79 \pm 0.06^{* * *} \\
(74.51)\end{array}$ & $\begin{array}{l}2.55 \pm 0.02^{* * *} \\
(83.04)\end{array}$ & $\begin{array}{l}2.49 \pm 0.03^{* * *} \\
(79.82)\end{array}$ & $\begin{array}{l}2.44 \pm 0.03^{* * *} \\
(81.63)\end{array}$ \\
\hline AEJf 500 & $2.29 \pm 0.08$ & $\begin{array}{l}3.03 \pm 0.18 \\
(21.27)\end{array}$ & $\begin{array}{l}2.95 \pm 0.07^{* *} \\
(55.70)\end{array}$ & $\begin{array}{l}3.14 \pm 0.04^{* * *} \\
(59.13)\end{array}$ & $\begin{array}{l}2.99 \pm 0.05^{* * *} \\
(59.06)\end{array}$ & $\begin{array}{l}2.57 \pm 0.04^{* * *} \\
(75.43)\end{array}$ & $\begin{array}{l}2.52 \pm 0.01^{* * *} \\
(76.53)\end{array}$ \\
\hline Aspirin $^{\circledR} 100$ & $2.31 \pm 0.04$ & $\begin{array}{l}2.98 \pm 0.14 \\
(28.72)\end{array}$ & $\begin{array}{l}3.02 \pm 0.12^{* *} \\
(52.34)\end{array}$ & $\begin{array}{l}2.99 \pm 0.06^{* * *} \\
(67.30)\end{array}$ & $\begin{array}{l}2.72 \pm 0.07^{* * *} \\
(76.02)\end{array}$ & $\begin{array}{l}2.65 \pm 0.05^{* * *} \\
(70.17)\end{array}$ & $\begin{array}{l}2.56 \pm 0.04^{* * *} \\
(74.48)\end{array}$ \\
\hline
\end{tabular}

${ }^{*} \mathrm{p}<0.05,{ }^{* *} \mathrm{p}<0.01,{ }^{* * *} \mathrm{p}<0.001, \mathrm{n}=6$ : Differences were significant when values of tested groups were compared to those of control group, at the corresponding time (same column). AEJf: Aqueous extract of Justicia flava 
are recorded in Table 6. The weight of wet granuloma content of the negative control group was $249 \pm 10.80 \mathrm{mg}$. The total AEJf induced a significant and dose-dependent reduction in the granuloma formation with an inhibition rate between $34.53 \%$ and $46.98 \%$. The inhibition percentage of the granuloma tissue formation of the group of rats treated with aspirin ${ }^{\circledR}$ was $49.79 \%$. The inhibitory effect of aspirin, the standard drug, used in this study was significant $(p<0.001)$ and higher than that of the AEJf. The dry weight of the granuloma tissue for the normal saline group was $32.8 \pm 2.11 \mathrm{mg}$. The AEJf at doses between 62.5 and $500 \mathrm{mg} / \mathrm{kg}$ bw caused a significant reduction in the dry weight of the granuloma tissue with an inhibition percentage between $45.73 \%$ and $59.45 \%$. The significant inhibitory power $(p<0.001)$ of aspirin ${ }^{\circledR}$ on the granuloma formation induced by the cotton pellets was $52.13 \%$ in rats after treatment

Effect of the AEJf on white blood cells in cotton pelletes-induced granuloma in rats

The variation in the number of white blood cells during the formation of granuloma induced in rats by the cotton pellet is registered in Table 7. The average number of white blood cells of the rats from the different groups was homogeneous and varied from $6.74 \pm 0.72 \times 10^{3} / \mu \mathrm{L}$ to $8.93 \pm 1.41 \times 10^{3} / \mu \mathrm{L}$ on the day 0 of the experiment. On the day 8 , the mean white blood cells count of rats in the normal saline group was significantly $(\mathrm{p}<0.001)$ increased from $7.48 \pm 0.71 \times 10^{3} / \mu \mathrm{L}$ to $15.23 \pm 0.45 \times 10^{3} / \mu \mathrm{L}$. In contrast, after oral administration with the AEJf at doses ranging from 62.5 to $500 \mathrm{mg} / \mathrm{kg}$ bw to the rats, the mean white blood cell count was reduced compared to that of the normal saline group. At the dose of $500 \mathrm{mg} / \mathrm{kg} \mathrm{bw}$, the decrease was significant $(\mathrm{p}<0.05)$. The reduction percentages were ranged from $17.07 \%$ to $39.98 \%$. Aspirin ${ }^{\circledR}$ used as anti-inflammatory standard drug, also caused a significant decrease in the number of white blood cells from $15.23 \pm 0.45 \times 10^{3} / \mu \mathrm{L}$ to $10.10 \pm 1.51 \times 10^{3} / \mu \mathrm{L}$. This decrease corresponded to $33.68 \%$ compared to the number of white blood cells in the normal saline group.

\section{Effect of the AEJf on the red blood cells and platelets}

The results of the change in the number of red blood cells and platelets obtained are shown in Table 8. The numbers of red blood cells and platelets of the six rats groups on day 0 was homogeneous and varied, respectively, from $6.75 \pm 0.32 \times 10^{6}$ to $8.24 \pm 0.23 \times 10^{6} / \mu \mathrm{L}$ and from $1080 \pm 52.6 \times 10^{3}$ to $1186 \pm 62 \times 10^{3} / \mu \mathrm{L}$. On the $8^{\text {th }}$ day after the induction and treatment of inflammation, the number of red blood cells as well as that of the platelets in the groups of rats treated with the AEIf and aspirin ${ }^{\circledR}$ did not change significantly $(p>0.05)$ compared to those of the negative control group. The number of red cells in the negative control group on day 8 was $7.46 \pm 0.30 \times 10^{6} / \mu \mathrm{L}$, while those recorded in groups treated with the AEJf at doses ranging from 62.5 to $500 \mathrm{mg} / \mathrm{kg}$ bw were between $7.44 \pm 0.28 \times 10^{6} / \mu \mathrm{L}$ and $7.99 \pm 0.37 \times 10^{6} / \mu \mathrm{L}$. As for the rats treated with aspirin ${ }^{\circledR}$, the number of red blood cells determined was $7.89 \pm 0.33 \times 10^{6} / \mu \mathrm{L}$. The number of platelets in the normal saline rats group significantly $(\mathrm{p}<0.05)$ raised from $1147 \pm 79.8 \times 10^{3} / \mu \mathrm{L}$ to $1487 \pm 102 \times 10^{3} / \mu \mathrm{L}$ during this study. The treatment of the rats with the

Table 4: Curative effect of the AEJf on carrageenan-induced edema in rats

\begin{tabular}{|c|c|c|c|c|c|c|c|}
\hline \multirow{2}{*}{$\begin{array}{l}\text { Treatment and } \\
\text { doses } \\
(\mathrm{mg} / \mathrm{kg} \mathrm{bw})\end{array}$} & \multirow{2}{*}{$\begin{array}{l}\text { Paw thickness }(\mathrm{mm}) \\
\text { before the injection } \\
\text { of carrageenan }\end{array}$} & \multirow{2}{*}{$\begin{array}{l}\text { Paw thickness }(\mathrm{mm}) \\
2 \mathrm{~h} \text { after the injection } \\
\text { of carrageenan }\end{array}$} & \multicolumn{5}{|c|}{$\begin{array}{l}\text { Paw thickness }(\mathrm{mm}) \text { after the injection of carrageenan (edema } \\
\text { reduction percentage) }\end{array}$} \\
\hline & & & $1 \mathrm{~h}$ & $2 \mathrm{~h}$ & $3 \mathrm{~h}$ & $4 \mathrm{~h}$ & $5 \mathrm{~h}$ \\
\hline $\begin{array}{l}\text { Normal saline } \\
\text { (control) }(\mathrm{mL} / \mathrm{kg} \mathrm{bw})\end{array}$ & $2.51 \pm 0.07$ & $5.61 \pm 0.23^{\# \# \#}$ & $5.27 \pm 0.08$ & $4.78 \pm 0.12$ & $4.59 \pm 0.08$ & $4.37 \pm 0.09$ & $4.12 \pm 0.09$ \\
\hline AEJf 62.5 & $2.54 \pm 0.04$ & $5.17 \pm 0.17^{\# \# \#}$ & $\begin{array}{l}4.25 \pm 0.17^{* *} \\
(19.35)\end{array}$ & $\begin{array}{l}3.87 \pm 0.12^{*} \\
(19.03)\end{array}$ & $\begin{array}{l}3.76 \pm 0.12^{*} \\
(18.08)\end{array}$ & $\begin{array}{l}3.36 \pm 0.11^{* * *} \\
(23.11)\end{array}$ & $\begin{array}{l}3.31 \pm 0.12^{* *} \\
(19.66)\end{array}$ \\
\hline AEJf 125 & $2.61 \pm 0.05$ & $5.36 \pm 0.35^{\# \# \#}$ & $\begin{array}{l}4.29 \pm 0.16^{* *} \\
(18.59)\end{array}$ & $\begin{array}{l}3.88 \pm 0.21^{*} \\
(18.82)\end{array}$ & $\begin{array}{l}3.67 \pm 0.25^{*} \\
(20.04)\end{array}$ & $\begin{array}{l}3.50 \pm 0.15^{* *} \\
(19.90)\end{array}$ & $\begin{array}{l}3.37 \pm 0.15^{* *} \\
(18.20)\end{array}$ \\
\hline AEJf 250 & $2.54 \pm 0.03$ & $5.35 \pm 0.42^{\# \# \#}$ & $\begin{array}{l}4.28 \pm 0.23^{* *} \\
(18.78)\end{array}$ & $\begin{array}{l}3.94 \pm 0.21^{*} \\
(17.57)\end{array}$ & $\begin{array}{l}3.8 \pm 0.28^{*} \\
(17.21)\end{array}$ & $\begin{array}{l}3.65 \pm 0.26^{*} \\
(16.47)\end{array}$ & $\begin{array}{l}3.33 \pm 0.23^{* *} \\
(19.17)\end{array}$ \\
\hline AEJf 500 & $2.53 \pm 0.06$ & $4.59 \pm 0.16^{\# \# \#}$ & $\begin{array}{l}3.82 \pm 0.12^{* * *} \\
(27.51)\end{array}$ & $\begin{array}{l}3.54 \pm 0.08^{* * *} \\
(25.94)\end{array}$ & $\begin{array}{l}3.30 \pm 0.10^{* * *} \\
(28.1)\end{array}$ & $\begin{array}{l}3.15 \pm 0.06^{* * *} \\
(27.91)\end{array}$ & $\begin{array}{l}3.06 \pm 0.10^{* * *} \\
(25.72)\end{array}$ \\
\hline Aspirin ${ }^{\circledR} 100$ & $2.58 \pm 0.11$ & $5.30 \pm 0.26^{\# \# \#}$ & $\begin{array}{l}4.32 \pm 0.20^{* *} \\
(18.03)\end{array}$ & $\begin{array}{l}3.78 \pm 0.27^{*} \\
(20.92)\end{array}$ & $\begin{array}{l}3.61 \pm 0.21^{* *} \\
(21.35)\end{array}$ & $\begin{array}{l}3.14 \pm 0.12^{* * *} \\
(28.15)\end{array}$ & $\begin{array}{l}3.04 \pm 0.09^{* * *} \\
(26.21)\end{array}$ \\
\hline
\end{tabular}

$\# \#$ $<<0.001$ : significant difference when the thickness of the rats paws, before the injection of carrageenan, was compared to that after the injection of carrageenan. $\mathrm{p}<0.05,{ }^{* *} \mathrm{p}<0.01,{ }^{* * *} \mathrm{p}<0.001, \mathrm{n}=6$ : significant difference when compared to the control group at the corresponding time (same column). AEJf: Aqueous extract of Justicia flava

Table 5: Curative effect of the AEJf on fresh egg albumin-induced edema in rats

\begin{tabular}{|c|c|c|c|c|c|c|c|}
\hline \multirow{2}{*}{$\begin{array}{l}\text { Treatment and } \\
\text { doses } \\
(\mathrm{mg} / \mathrm{kg} \mathrm{bw})\end{array}$} & \multirow{2}{*}{$\begin{array}{l}\text { Paw thickness (mm) } \\
\text { before the injection } \\
\text { of egg albumin }\end{array}$} & \multirow{2}{*}{$\begin{array}{l}\text { Paw thickness }(\mathrm{mm}) \\
1 \mathrm{~h} \text { after the injection } \\
\text { of egg albumin }\end{array}$} & \multicolumn{5}{|c|}{$\begin{array}{l}\text { Paw thickness }(\mathrm{mm}) \text { after egg albumin injection } \\
\text { (edema reduction percentage) }\end{array}$} \\
\hline & & & $1 \mathrm{~h}$ & $2 \mathrm{~h}$ & $3 \mathrm{~h}$ & $4 \mathrm{~h}$ & $5 \mathrm{~h}$ \\
\hline $\begin{array}{l}\text { Normal saline } \\
\text { (control) (mL/kg bw) }\end{array}$ & $2.76 \pm 0.08$ & $6.37 \pm 0.13^{\# \# \#}$ & $6.41 \pm 0.28$ & $5.94 \pm 0.34$ & $5.05 \pm 0.27$ & $4.50 \pm 0.31$ & $4.12 \pm 0.24$ \\
\hline AEJf 62.5 & $2.83 \pm 0.21$ & $6.68 \pm 0.21^{\# \# \#}$ & $\begin{array}{l}5.51 \pm 0.21 \\
(14.04)\end{array}$ & $\begin{array}{l}4.82 \pm 0.21^{* * *} \\
(18.85)\end{array}$ & $\begin{array}{l}4.27 \pm 0.21^{* * *} \\
(15.44)\end{array}$ & $\begin{array}{l}4.10 \pm 0.21 \\
(8.88)\end{array}$ & $\begin{array}{l}3.67 \pm 0.21 \\
(10.92)\end{array}$ \\
\hline AEJf 125 & $2.76 \pm 0.21$ & $6.42 \pm 0.24^{\# \# \#}$ & $\begin{array}{l}4.97 \pm 0.33^{* * *} \\
(22.46)\end{array}$ & $\begin{array}{l}4.27 \pm 0.31^{* * *} \\
(28.11)\end{array}$ & $\begin{array}{l}3.89 \pm 0.39 * * * \\
(22.97)\end{array}$ & $\begin{array}{l}3.60 \pm 0.37 * * * \\
(20)\end{array}$ & $\begin{array}{l}3.45 \pm 0.30^{*} \\
(16.26)\end{array}$ \\
\hline AEJf 250 & $2.88 \pm 0.23$ & $5.99 \pm 0.33^{\# \# \#}$ & $\begin{array}{l}4.79 \pm 0.16^{* * *} \\
(25.27)\end{array}$ & $\begin{array}{l}4.18 \pm 0.23^{* * *} \\
(29.62)\end{array}$ & $\begin{array}{l}4.02 \pm 0.21^{* * *} \\
(20.39)\end{array}$ & $\begin{array}{l}3.65 \pm 0.05^{* *} \\
(18.88)\end{array}$ & $\begin{array}{l}3.58 \pm 0.25 \\
(13.10)\end{array}$ \\
\hline AEJf 500 & $2.93 \pm 0.15$ & $6.01 \pm 0.12^{\# \# \#}$ & $\begin{array}{l}5.05 \pm 0.25^{* *} \\
(21.21)\end{array}$ & $\begin{array}{l}4.32 \pm 0.30^{* * *} \\
(27.27)\end{array}$ & $\begin{array}{l}4.05 \pm 0.15^{* * *} \\
(19.80)\end{array}$ & $\begin{array}{l}3.77 \pm 0.26^{* *} \\
(16.22)\end{array}$ & $\begin{array}{l}3.55 \pm 0.17 \\
(13.83)\end{array}$ \\
\hline Aspirin $^{\circledast} 100$ & $2.59 \pm 0.32$ & $6.49 \pm 0.42^{\# \# \#}$ & $\begin{array}{l}4.98 \pm 0.37^{* * *} \\
(22.30)\end{array}$ & $\begin{array}{l}4.69 \pm 0.39 * * * \\
(21.04)\end{array}$ & $\begin{array}{l}4.02 \pm 0.36^{* * *} \\
(20.39)\end{array}$ & $\begin{array}{l}3.51 \pm 0.34^{* * *} \\
(22)\end{array}$ & $\begin{array}{l}3.28 \pm 0.38^{* *} \\
(20.38)\end{array}$ \\
\hline
\end{tabular}

\#\#\# $<<0.001$ : significant difference when the thickness of the rats paws, before injection of the egg albumin was compared to that after the injection of egg albumin. $\mathrm{p}<0.05,{ }^{* *} \mathrm{p}<0.01,{ }^{* * *} \mathrm{p}<0.001, \mathrm{n}=6$ : significant difference when compared to the control group at the corresponding time. AEJf: Aqueous extract of Justicia flava 
Table 6: Effect of AEJf on the formation of granuloma induced in the rat by cotton pellet

\begin{tabular}{lllll}
\hline $\begin{array}{l}\text { Treatment } \\
\text { and doses } \\
\text { (mg/kg } \\
\text { bw) }\end{array}$ & $\begin{array}{l}\text { Average } \\
\text { weight of wet } \\
\text { granuloma } \\
\text { content (mg) }\end{array}$ & $\begin{array}{l}\text { Inhibition } \\
\text { Percentage } \\
\text { (\%) }\end{array}$ & $\begin{array}{l}\text { Average } \\
\text { weight of dry } \\
\text { granuloma } \\
\text { content (mg) }\end{array}$ & $\begin{array}{l}\text { Inhibition } \\
\text { (\%) }\end{array}$ \\
\hline $\begin{array}{l}\text { Normal } \\
\text { saline }\end{array}$ & $249 \pm 10.8$ & - & $32.8 \pm 2.11$ & - \\
(control) & & & & \\
(mL/kg & & & & \\
bw) & & & & \\
AEJf 62.5 & $163 \pm 25.3^{* *}$ & 34.53 & $17.8 \pm 1.89^{* * *}$ & 45.73 \\
AEJf 125 & $154 \pm 13.4^{* *}$ & 38.15 & $16.2 \pm 1.34^{* * *}$ & 50.60 \\
AEJf 250 & $133 \pm 15.8^{* * *}$ & 46.58 & $15.9 \pm 3.00^{* * *}$ & 51.52 \\
AEJf 500 & $132 \pm 16.6^{* * *}$ & 46.98 & $13.3 \pm 1.19^{* * *}$ & 59.45 \\
Aspirin ${ }^{\circledR}$ & $125 \pm 15.7^{* * *}$ & 49.79 & $15.7 \pm 1.75^{* * *}$ & 52.13 \\
100 & & & & \\
\hline
\end{tabular}

${ }^{* *} \mathrm{p}<0.01,{ }^{* * *} \mathrm{p}<0.001, \mathrm{n}=6$ : Comparison between $\mathrm{NaCl}$ control group and groups treated at day 8 after induction of inflammation. AEJf: Aqueous extract of Justicia flava

Table 7: Effect of the AEJf on white blood cells

\begin{tabular}{|c|c|c|}
\hline \multirow[t]{2}{*}{$\begin{array}{l}\text { Treatment and doses } \\
(\mathrm{mg} / \mathrm{kg} \mathrm{bw})\end{array}$} & \multicolumn{2}{|c|}{$\begin{array}{l}\text { Average number of white blood cells } \\
\left(\times 10^{3} / \mu \mathrm{L}\right) /(\text { reduction percentage) }\end{array}$} \\
\hline & Day 0 & Day 8 \\
\hline $\begin{array}{l}\text { Normal saline } \\
\text { (control) }(\mathrm{mL} / \mathrm{kg} \mathrm{bw})\end{array}$ & $7.48 \pm 0.71$ & $15.23 \pm 0.45^{\# \# \#}$ \\
\hline AEJf 62.5 & $8.93 \pm 1.41$ & $11.34 \pm 0.93(25.54)$ \\
\hline AEJf 125 & $6.74 \pm 0.72$ & $12.63 \pm 2.20(17.07)$ \\
\hline AEJf 250 & $7.17 \pm 0.89$ & $11.84 \pm 1.22(22.25)$ \\
\hline AEJf 500 & $7.80 \pm 0.89$ & $9.14 \pm 0.53^{*}(39.98)$ \\
\hline Aspirin ${ }^{\circledR} 100$ & $7.82 \pm 0.55$ & $10.10 \pm 1.51^{*}(33.68)$ \\
\hline
\end{tabular}

AEJf (62.5-500 mg/kg bw) caused a non-significant decrease ( $>0.05)$ in the number of blood platelets with reduction percentages between $12.57 \%$ and $22.66 \%$ compared to that of the negative control group. The reduction percentage showed by aspirin ${ }^{\circledR}$ was $25.35 \%$ compared to the normal saline group.

\section{Effect of the AEJf on rats body weight}

The results of the changes in experimental rats' body weight over the 8 days are shown in Table 9. The weight of the rats in each group was decreased compared to their weights on the day 0 . The weight loss of rats in the negative control group was $10.2 \pm 3.83 \%$. However, weight loss in groups treated with the AEJf was significantly $(p<0.05)$ lower than control group with values ranging from $03 \pm 0.64 \%$ to $06.13 \pm 0.80 \%$. The weight of the rats treated with aspirin ${ }^{\circledast}$ was also decreased to $04.99 \pm 1.21 \%$ on the $8^{\text {th }}$ day of treatment.

\section{DISCUSSION}

The acute anti-inflammatory potential of the AEJf was evaluated in rats using inflammation experimental models in rats. The AEJf inhibited carrageenan-induced edema and fresh egg albumin-induced edema during preventive and curative studies at all stages of the inflammatory process. Thus, this extract could have an antagonistic action on the release or on the effect of pro-inflammatory substances such as histamine, serotonin, bradykinin, and prostaglandin. Indeed, the injection of phlogogenic agents (carrageenan, dextran, fresh egg albumin, and others) in the rat's paw causes a local inflammation due to tissue injury, which results in the release of several mediators responsible of inflammatory process. This inflammatory response has two-phases. The initial phase lasts about $1 \mathrm{~h}$; it's due to the release
Table 8: Effect of the AEJf on the red blood cells and blood platelets

\begin{tabular}{|c|c|c|c|c|}
\hline \multirow{3}{*}{$\begin{array}{l}\text { Treatment } \\
\text { and doses } \\
\text { (mg/kg } \\
\text { bw) }\end{array}$} & \multicolumn{4}{|c|}{$\begin{array}{l}\text { Number of red blood cells and platelets/(variation } \\
\text { percentage) }\end{array}$} \\
\hline & \multicolumn{2}{|l|}{ Day 0} & \multicolumn{2}{|l|}{ Day 8} \\
\hline & $\begin{array}{l}\mathrm{RBC} \\
\left(\times 10^{6} / \mu \mathrm{L}\right)\end{array}$ & $\begin{array}{l}\text { PLT } \\
\left(\times 10^{3} / \mu L\right)\end{array}$ & $\begin{array}{l}\mathrm{RBC} \\
\left(\times 10^{6} / \mu \mathrm{L}\right)\end{array}$ & $\begin{array}{l}\text { PLT } \\
\left(\times 10^{3} / \mu \mathrm{L}\right)\end{array}$ \\
\hline $\begin{array}{l}\text { Normal } \\
\text { saline } \\
\text { (control) } \\
\text { (mL/kg } \\
\text { bw) }\end{array}$ & $7.30 \pm 0.18$ & $1147 \pm 79.8$ & $7.46 \pm 0.36$ & $1487 \pm 102^{*}$ \\
\hline AEJf 62.5 & $7.67 \pm 0.17$ & $1080 \pm 52.6$ & $\begin{array}{l}7.44 \pm 0.28^{\mathrm{ns}} \\
(-0.26)\end{array}$ & $\begin{array}{l}1300 \pm 128^{\mathrm{ns}} \\
(-12.57)\end{array}$ \\
\hline AEJf 125 & $7.62 \pm 0.18$ & $1154 \pm 49.2$ & $\begin{array}{l}7.96 \pm 0.20^{\mathrm{ns}} \\
(+6.7)\end{array}$ & $\begin{array}{l}1204 \pm 139^{\mathrm{ns}} \\
(-19.03)\end{array}$ \\
\hline AEJf 250 & $7.55 \pm 0.35$ & $1186 \pm 62.0$ & $\begin{array}{l}7.94 \pm 0.19^{\text {ns }} \\
(+6.43)\end{array}$ & $\begin{array}{l}1230 \pm 62.8^{\text {ns }} \\
(-17.28)\end{array}$ \\
\hline AEJf 500 & $6.75 \pm 0.32$ & $1083 \pm 64.9$ & $\begin{array}{l}7.99 \pm 0.37^{\mathrm{ns}} \\
(+7.1)\end{array}$ & $\begin{array}{l}1150 \pm 76.1^{\text {ns }} \\
(-22.66)\end{array}$ \\
\hline $\begin{array}{l}\text { Aspirin }^{\circledR} \\
100\end{array}$ & $8.24 \pm 0.23$ & $1133 \pm 25.5$ & $\begin{array}{l}7.89 \pm 0.33^{\text {ns }} \\
(+5.76)\end{array}$ & $\begin{array}{l}1110 \pm 92.1^{\text {ns }} \\
(-25.35)\end{array}$ \\
\hline
\end{tabular}

" $\mathrm{p}<0.05, \mathrm{n}=6$ : Comparison between negative controls on day 0 and day 8 of the experiment, $n s=$ not significant $(\mathrm{p}>0.05)$, comparison between normal saline group and treated groups. AEJf: Aqueous extract of Justicia flava, RBC: Red blood cells, PLT: Platelets, (-): Reduction; (+): Augmentation

Table 9: Effect of the AEJf on the rats body weight

\begin{tabular}{llll}
\hline $\begin{array}{l}\text { Treatment and doses } \\
\text { (mg/kg bw) }\end{array}$ & \multicolumn{2}{l}{$\begin{array}{l}\text { Average weight of } \\
\text { rats (g) }\end{array}$} & Weight loss \% \\
\cline { 2 - 3 } & Day 0 & Day 8 & \\
\hline $\begin{array}{llll}\text { Normal saline (control) } \\
\text { (mL/kg bw) }\end{array}$ & $186 \pm 8.61$ & $167 \pm 10.3$ & $10.2 \pm 3.83$ \\
AEJf 62.5 & $189 \pm 3.86$ & $173 \pm 5.90$ & $08.3 \pm 3.57$ \\
AEJf 125 & $190 \pm 11.6$ & $175 \pm 14.8$ & $08.13 \pm 2.93$ \\
AEJf 250 & $217 \pm 14.6$ & $204 \pm 14.3$ & $06.13 \pm 0.80 * *$ \\
AEJf 500 & $203 \pm 9.05$ & $197 \pm 10.0$ & $03 \pm 0.64 * *$ \\
Aspirin ${ }^{\circledR} 100$ & $189 \pm 10.8$ & $180 \pm 12.2$ & $04.99 \pm 1.21 *$ \\
\hline *p<0.05, **p<0.01, $\mathrm{n}=6$ : Comparison between values of normal saline control \\
group and those of Justica flava aqueous extract treated groups. AEJf: Aqueous \\
extract of Justicia flava
\end{tabular}

of histamine and serotonin. Bradykinin is released in the second phase between $1 \frac{1}{2} \mathrm{~h}$ and $3 \mathrm{~h}$. Prostaglandin release occurs after the $3^{\text {rd }} \mathrm{h}$ [18]. Strong inhibitions of edema were observed throughout the experiment for the preventive effect $(77.63 \%$ and $61 \%$, respectively, for carrageenan and fresh egg albumin) and for the curative effect (28.1\% and $29.62 \%$, respectively, for carrageenan and fresh egg albumin). These results suggest that the inhibitory action of the AEJf may exert more control over the release of all the chemical mediators responsible for the inflammatory process during the first and the second phases. These results are similar to those of Yoon and Lee [19] who showed that the ethanolic extract of Bacopa monnieri, Cassia fistula, and Phyllanthus polyphyllus at doses ranging from 1.25 to $12.5 \mathrm{mg} / \mathrm{kg}$ bw reduced the egg-albumin edema by $49 \%$ after $45 \mathrm{~min}$ of experimentation. On the other hand, some authors revealed that the methanolic extract of Gladiolus segetum at $500 \mathrm{mg} / \mathrm{kg}$ bw inhibited the egg-albumin edema by $52.67 \%$ after $5 \mathrm{~h}$ of experimentation [20]. Moreover, at $100 \mathrm{mg} / \mathrm{kg}$ bw, the stem bark decoction of Stemonocoleus micranthus significantly $(\mathrm{p}<0.05)$ inhibited carrageenan-induced edema by $57.1 \%$ at $5^{\text {th }} \mathrm{h}$ posttreatment compared to control [21]. As stated above, histamine is a key mediator of the first phase of acute inflammation. Thus, the effect of the AEJf was investigated to assess its action on this mediator. This study unraveled that histamine-induced edema in the rat was significantly inhibited by prior administration of the AEJf at doses ranging from 62.5 
to $500 \mathrm{mg} / \mathrm{kg}$ bw. Indeed, an inhibitory effect of the AEIf was observed from the $1^{\text {st }} \mathrm{h}$ after histamine injection in rats. Therefore, it could be hypothesized that the AEJf impeded either the release of histamine from mast cells or its effect. These results corroborate those of Silva et al. [22]. These authors showed that the ethanolic extract of Annona vepretorum $(100 \mathrm{mg} / \mathrm{kg} \mathrm{bw})$ significantly inhibited histamine-induced edema. Likewise Mukarram and Syed also showed that the ethyl acetate fraction of Teucrium stocksianum had antihistamine effect ranging from $18.14 \%$ to $31.04 \%$ [23]. This antihistamine effect was observed $2 \mathrm{~h}$ after histamine injection. The AEJf significantly inhibited the weight of granuloma induced by autoclaved sterilized cotton pellet in the rats. The induction of inflammation by autoclaved sterilized cotton pellets during 8 days of experimentation was characterized by the formation of granulomas resulting from the proliferation of fibroblasts and the infiltration of neutrophils with exudation of fluids [24]. Repeated treatment of rats with the AEJf at doses ranging from 62.5 to $500 \mathrm{mg} / \mathrm{kg}$ bw caused a maximum reduction in the mean weight of wet (46.98\%) and dry (59.45\%) granulomas compared to negative control group. This inhibition of the average weight of wet and dry granuloma contents showed that the AEJf may have suppressed the proliferation phase of inflammation characterized by vascular permeability, fluid absorption at the level of cotton pellets, and proliferation of macrophages and neutrophils. These results are similar to those of Rawat et al. who disclosed that the methanolic extract of Kigelia pinnata leaves at $400 \mathrm{mg} / \mathrm{kg}$ bw inhibited the average weight of wet cotton pellets by $45.15 \%$ and that of dry cotton pellets by $53.6 \%$ [25]. In addition, other authors showed that at $400 \mathrm{mg} / \mathrm{kg}$ bw, the acetone extract of Solenostemma argel leaves significantly $(\mathrm{p}<0.05)$ reduced wet cotton peletts by $67.74 \%$ and that of dry cotton pellet by $70.58 \%$ [26]. The assessment of rats body weight during granuloma formation induced by the cotton pellets indicated a decrease in rats body weight in the normal saline group. The body weight of the rats treated with the AEJf at the different doses also decreased but less than that of the normal saline group without any significant difference. The significant loss of weight of the normal saline rats group could be due to a change in the metabolic activity according to Walz et al. [27]. The slight restoration of body weight recorded in the groups of rats treated with the AEJf could be due to a beneficial effect on the digestive or nervous system. These findings are contrary to those of Mishra et al. [28] who showed that animal body weight dropped significantly after repeated administration of the hydroethanolic extract of Mollugo pentaphylla in a cotton pellet induced inflammation study. These differences could be due to the action of constituents contained in the extracts of the different plants. Daily oral treatment of the rats with aspirin and the AEJf exhibited a significant decrease $(p<0.05)$ in the number of white blood cells which was raised by inflammation. Indeed, the insertion of sterilized cotton pellets into the dorsal region of the rats generated a chronic inflammation with an active release of the leucocytes thereafter.

This proliferation of white blood cells (macrophages, neutrophils) would maintain the defensive activity of the host defense system [29]. According to Chen et al. [30], an active release and infiltration of white blood cells are a biological sign of inflammation. Therefore, a significant decrease in the number of white blood cells in the presence of the AEJf could indicate that this extract contains substances that would act on the rats' immune system to inhibit the proliferation phase of inflammation characterized by the release of white blood cells. The results of the present work are similar to those of Mishra et al. [28]. These authors showed that the hydro-ethanolic extract of M. pentaphylla significantly reduced the number of white blood cells at doses of 200 and $400 \mathrm{mg} / \mathrm{kg}$ bw in cotton pellet-induced inflammation.

The number of red blood cells did not change significantly after 8 days of induction and treatment of chronic inflammation induced in rats by the cotton pellet. Indeed, the exposure of the red blood cell membrane to inflammatory substances released after the implantation of the cotton pellets had no significant influence on these cells. As to the platelet level, the number was significantly increased $(p<0.05)$ in the normal saline group after 8 days of induction of inflammation in rats by implantation of the cotton pellets. The number of blood platelets in the rats treated with the total AEJf did not decrease significantly compared to that of the negative control group. The platelet profile was thereby not significantly affected by the total AEJf. The total AEJf did not affect the platelet profile. Similar results were obtained by Marref et al. [20] who found out that the methanolic extract of $G$. segetum did not significantly alter the number of blood platelets compared to control group in inflammation elicited by cotton pellet insertion in rats. Similarly Lima et al. [31] showed that the crude extract of Verbena litoralis used in the cotton pellets test did not affect the platelet count compared to the negative control group.

\section{CONCLUSION}

The AEJf administered orally to rats has remarkable anti-inflammatory properties. This could justify the traditional use of this plant in the treatment of body aches, pain, and fever.

\section{ACKNOWLEDGMENT}

The authors are thankful to Dr. OUSSOU N'Guessan Jean-Baptiste, a lecturer and researcher at the Laboratory of Physiology, Pharmacology and Pharmacopoeia (Nangui Abrogoua University, Abidjan - Côte d'Ivoire) for the technical assistance and his help in translating this manuscript from French into English.

\section{AUTHORS' CONTRIBUTIONS}

All authors made substantial contribution to conception and design, acquisition of data, or analysis and interpretation of data, took part in drafting the article, or revising it critically for intellectual content. All authors are therefore eligible to be on author.

\section{CONFLICT OF INTEREST}

The authors declare no conflict of interest.

\section{REFERENCES}

1. Medzhitov R. Inflammation: New adventures of an old flame. Cell 2010;140:771-6.

2. Vishal V, Sharma GN, Gaur M, Bairwa R. A review on some plants having anti-inflammatory activity. J Phytopharm 2014;3:214-21.

3. Cooke JP. Inflammation and its role in regeneration and repair. Circ Res 2019; $124: 1166-8$.

4. $\mathrm{Ng}$ SC. Non-steroidal anti-inflammatory drugs-uses and complications. Singapore Med J 1992;33:510-3.

5. Bouquet A, Debray M. Plantes médicinales de Côte d'Ivoire. In: Edition de L'office de la Recherche Scientifique Et Technique Outremer. Vol. 32. Paris: ORSTOM; 1974. p. 10-2.

6. Grubben GJ, Denton OA. Plant resources of tropical Africa-2. Nord J Bot 2004;23:298-324.

7. Ramesar S, Baijnath H, Govender T, Mackraj I. Angiotensin I-converting enzyme inhibitor activity of nutritive plants in KwaZulunatal. J Med Food 2008;11:331-6.

8. Corrêa GM, Antônio F, Alcântara C. Chemical constituents and biological activities of species of Justicia. Braz J Pharmacogn 2011;22:220-38

9. Gomez-Verjan JC, Reyes CR, Aguilar MI. Chemistry and pharmacology of selected Asian and American medicinal species of Justicia. Bioact Phytochem Persp Mod Med 2012;1:404-7.

10. Agyare C, Bempah SB, Boakye YD, Ayande PG, Adarkwa-YM, Mensah KB. Evaluation of antimicrobial and wound healing potential of Justicia flava and Lannea welwitschii. Evid Based Complement Alternat Med 2013;2013:632927.

11. OCDE. Série Sur les Principes de Bonnes Pratiques de Laboratoire et Vérification du Respect de Ces Principes. Vol. 17. Paris, France: ENV/ MC/CHEM, OCDE; 1998. p. 22-3.

12. European Union. Commission implementing decision of 14 November 2012 establishing a common format for the submission of the information pursuant to Directive 2010/63/EU of the European parliament and of the council on the protection of animals used for scientific purposes (notified under document C (2012) 8064) text with EEA relevance. Spec Ed Croat 2012;15:163-80.

13. Winter CA, Risley EA, Nuss GW. Carrageenan-induced edema in hind- 
paw of rat as an assay for antiinflammatory drugs. J Pharmacol Exp Ther 1962;141:369-73

14. Meshram GG, Kumar A, Rizvi W, Tripathi CD, Kan RA. Evaluation of the anti-inflammatory activity of the aqueous and ethanolic extract of the leaves of Albizia lebbeck in rats. J Tradit Complement Med 2015;6:172-5.

15. Gutiérrez-Rebolledo GA, Garduño-Siciliano L, Chávez-Rueda AK, Siordia-Reyes AG, Zamilpa A, Jiménez-Arellanes MA. In vivo antiarthritic and antioxidant effect from the standardized ethanolic extract of Moussonia deppeana. Braz J Pharmacogn 2018;28:198-206.

16. Muhammad N, Saeed M, Khan H. Antipyretic, analgesic and antiinflammatory activity of Viola betonicifolia whole plant. BMC Complement Altern Med 2012;12:59-67.

17. Kumar K, Ganesh M, Baskar S, Srinivasan K, Kanagasabai R, Sambathkumar R, et al. Evaluation of anti-inflammatory activity and toxicity studies of Chloroxylon sweitenia in Rats. Anc Sci Life 2006;25:33-43.

18. Abdulkhaleq LA, Assi MA, Abdullah R, Zamri-Saad M, TaufiqYap YH, Hezmee MN. The crucial roles of inflammatory mediators in inflammation: A review. Vet World 2018;11:627-35.

19. Yoon WH, Lee KH. Anti-inflammatory, anti-arthritic and analgesic effect of the herbal extract made from Bacopa monnieriis, Cassia fistula and Phyllanthus polyphyllus. Nat Prod Sci 2017;23:108-12.

20. Marref SE, Benkiki N, Melakhessou MA, Bouzidi S. Acute toxicity, anti-ulcer and anti-inflammatory effects of methanol extract of Gladiolus segetum in Rats. Pharmacogn J 2018;10:758-62.

21. Mbaoji FN, Onwuka AM, Onu S, Peter IE, Nweze JA, Okonta LE. Evaluation of methanol-dichloromethane extract of Stemonocoleus micranthus harms (fabaceae) stem bark for anti-inflammatory and immunomodulatory activities. Evid Based Complement Alternat Med 2020;2020:1738163.

22. Silva JC, Araújo CS, Lima-Saraiva SR, Oliveira-Junior RG, Diniz TC,
Wanderley CW, et al. Antinociceptive and anti-inflammatory activities of the ethanolic extract of Annona vepretorum Mart. (Annonaceae) in rodents. Complement Alternat Med 2015;15:197-206.

23. Mukarram S, Syed M. A possible anti-inflammatory mechanism of ethyl acetate extracts of Teucrium stocksianum Bioss. Complement Alternat Med 2015;15:299-305.

24. Zumla A, James GD. Granulomatous infections: Etiology and classification. Clin Infect Dis 1996;23:146-58.

25. Rawat M, Parmar N, Kumar T. Evaluation of anti-inflammatory potential of Kigelia pinnata leaf extract in wistar rats. Asian J Pharm Clin Res 2012;5:95-7.

26. Benmaarouf DK, Pinto DC, China B, Zenia S, Bendesari KB, BenMahdi MH. Chemical analysis, antioxidant, anti-inflammatory and antinociceptive effects of acetone extract of Algerian Solenostemma argel (delile) hayne leaves. Int J Curr Pharm Res 2020;12:72-81.

27. Walz DT, Dimartino MJ, Misher A. Adjuvant induced arthritis in rats. II. Drug effects on physiologic, biochemical and immunologic parameters. J Pharmacol Exp Ther 1971;178:223-31.

28. Mishra NK, Panda RK, Rajakumar V, Kumar S, Tejonidhi K, Mishra G. Evaluation of Anti-inflammatory activity and dose selection of Mollugo pentaphylla by using cotton pellet induced granuloma in rat. Int J Pharm Sci Health Res 2010;1:155-62.

29. Nakase H, Daisuke H, Tomoya I. The phagocytic function of macrophage-enforcing innate immunity and tissue homeostasis. Int J Mol Sci 2017;19:1-14.

30. Chen L, Deng H, Cui1 H, Fang J, Zuo1 Z, Deng J, et al. Inflammatory responses and inflammation-associated diseases in organs. Oncotarget 2018;9:7204-18.

31. Lima R, Brondani JC, Dornelles RC, Lhamas CL, Faccin H, Silva CV, et al. Anti-inflammatory activity and identification of the Verbena litoralis Kunth crude extract constituents. Braz J Pharm Sci 2020;56:1-8. 